\title{
New heteroaryl carbamates: synthesis and biological screening in vitro and in mammalian cells of wild-type and mutant HIV-protease inhibitors.
}

\author{
Francesco Tramutola $^{\mathrm{a}, 1}$, Maria Francesca Armentano ${ }^{\mathrm{a}, 1}$, Federico Berti ${ }^{\mathrm{b}}$, Lucia Chiummiento ${ }^{\mathrm{a}}$, Paolo \\ Lupattelli $^{\mathrm{a}}$, Rosarita D’Orsi ${ }^{\mathrm{a}}$, Rocchina Miglionico ${ }^{\mathrm{a}}$, Luigi Milella ${ }^{\mathrm{a}}$, Faustino Bisaccia ${ }^{\mathrm{a}}$, Maria \\ Funicello $^{\mathrm{a}, *}$ \\ ${ }^{a}$ Dipartimento di Scienze, Università della Basilicata, Via Ateneo Lucano 10, 85100 Potenza, Italy. \\ ${ }^{\mathrm{b}}$ Dipartimento di Scienze Chimiche e Farmaceutiche, Università di Trieste, via Giorgieri, 1, 34127 \\ Trieste, Italy.
}

In honor of professor Carlo Bonini for his $70^{\circ}$ birthday

Keywords: HIV-protease inhibitors; heteroaryl carbamates; drug-resistance; synthesis, biological screening; modeling.

\begin{abstract}
:
New heteroaryl HIV-protease inhibitors bearing a carbamoyl spacer were synthesized in few steps and high yield, from commercially available homochiral epoxides. Different substitution patterns were introduced onto a given isopropanoyl-sulfonamide core that can have either $\mathrm{H}$ or benzyl group. The in vitro inhibition activity against recombinant protease showed a general beneficial effect of both carbamoyl moiety and the benzyl group, ranging the $\mathrm{IC}_{50}$ values between 11 and 0.6 nM. In particular, benzofuryl and indolyl derivatives showed $\mathrm{IC}_{50}$ values among the best for such structurally simple inhibitors. Docking analysis allowed to identify the favorable situation of such derivatives in terms of number of interactions in the active site, supporting the experimental results. The inhibition activity was also confirmed in HEK293 mammalian cells and was maintained against protease mutants. Furthermore, the metabolic stability was comparable with that of the commercially available inhibitors.
\end{abstract}

\section{Introduction}

The AIDS epidemic is still one of the most challenging problems although great efforts are made to the discovery of new drugs for its treatment. ${ }^{1}$ Among many strategies to combat the disease, highly active antiretroviral therapy (HAART) containing at least one of HIV-1 protease inhibitors (PIs) is considered as the most effective treatment. ${ }^{2}$

In fact, the HIV-1 aspartic protease (HIV-PR) is essential for the production of mature HIV particles and plays a key role in maintaining infectivity. Currently, nine approved PIs are 
commercially available and have definitely improved both the quality of life and life expectancy of HIV-infected patients. However, because of the rapid genomic evolution of the HIV, an inevitable consequence in the treatment of the infection has been the rise of drug resistance and therefore the dramatically reduction of the commercial inhibitors efficiency.

Thus, both the emergence of highly mutated viral strains cross-resistant to antivirals and the occurrence of various debilitating side effects, and not last the high cost of HAART, prompted scientists to seek novel PIs, desirably with alternative frameworks.

The last commercially available inhibitor, Darunavir, is actually the only one active against mutated virus; moreover, it is particularly interesting because of its double inhibitory activity: inhibition of the dimerization and inhibition of proteolytic activity. ${ }^{3}$

During our investigation on new peptidomimetics and non peptidic inhibitors, we found beneficial effect of heteroaryl rings as $\mathrm{P} 2$ ligand. $^{4}$

In particular, the systematic study on derivatives of simple substituted stereodefined isopropanolamine core showed the high effect of the functionality between the heteroaryl group and the core together with the type of heteroaryl group. Promising $\mathrm{IC}_{50}$ value was obtained with benzothienyl derivative 1 (Figure 1). ${ }^{4 c}$ With the aim to take advantage of an enhancement of $\mathrm{H}$ bond interactions, we synthesized in few steps and with high yield new simple benzofuryl, indolyl and benzothienyl HIV protease inhibitors 2 bearing a carboxyamide spacer, which in general showed in vitro activity against native protease, with $\mathrm{IC}_{50}$ values in the range of $1-15 \mathrm{nM}$. Such derivatives also showed inhibition activity in mammalian cells, demonstrating their promising potential. $^{5}$
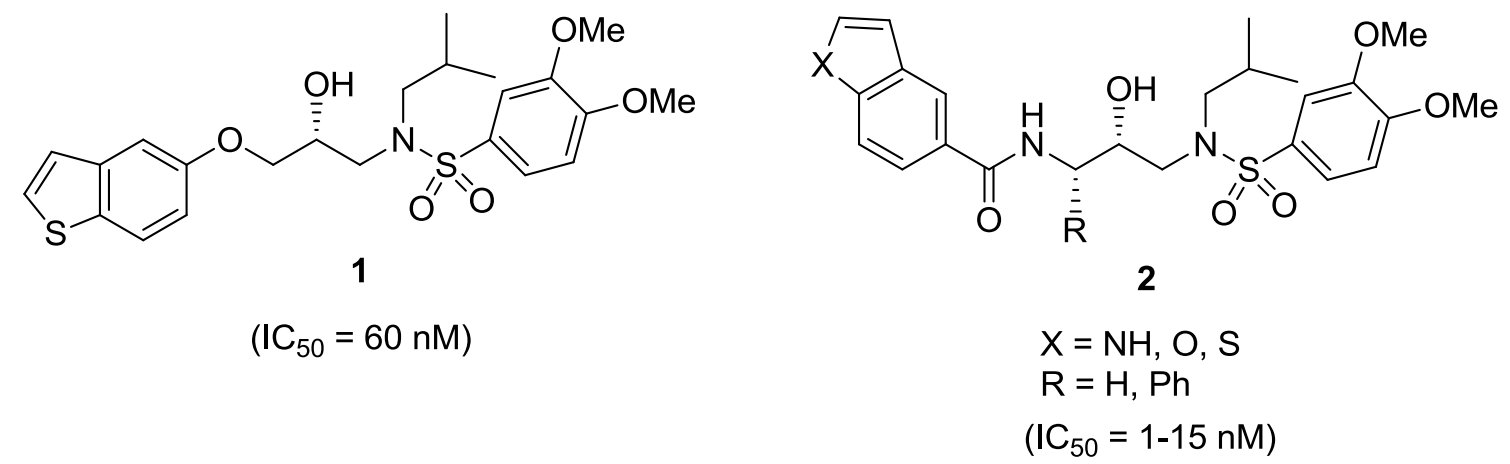

Figure 1

In our recent studies, ${ }^{4 a}$ some carbamoyl structures containing indole ring as heteroaryl mojety (compound 3, figure 2) were examined, but the biological activity resulted only in the $\mu \mathrm{M}$ range. 
As it can be seen, compound $\mathbf{3}$ bears the carbamoyl group, which is reversed respect to the wellknown Darunavir and TMC-126<smiles>COc1ccc2c(c1)C(C)CN(C[C@H](O)COC(=O)Nc1ccc3[nH]ccc3c1)S2(=O)=O</smiles>

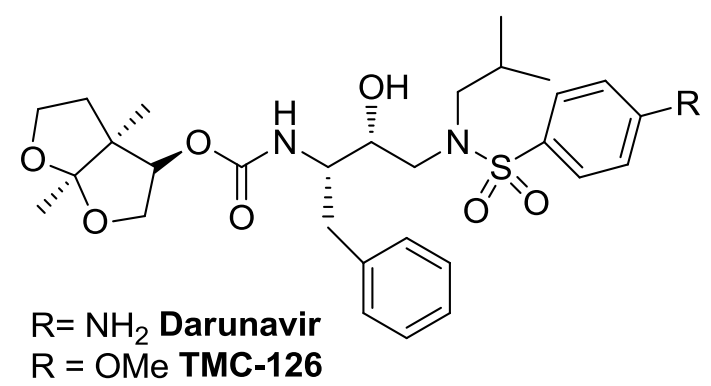

Figure 2

Thus, following the concept of targeting the protein backbone, with the aim to design simple nonpeptidic heteroaryl structures, we planned a systematic study on the synthesis and inhibition activity of new derivatives with general structure $\mathbf{A}$, in which the heterocycle is spaced from the core by a carbamoyl function in the same disposition of Darunavir and TMC-126. The type of heteroaryl group $(\mathrm{X}=\mathrm{O}, \mathrm{NH}, \mathrm{S}$ ) and the core were modified, with the presence of either $\mathrm{H}$ or benzyl as $\mathrm{R}$ substituent.<smiles>[X]c1ccc2cc(OC(=O)N[C@@H]([R])[C@@H](O)CN(CC(C)C)S(=O)(=O)c3ccc(OC)cc3)ccc2c1</smiles>

A

$X=\mathrm{NH}, \mathrm{O}, \mathrm{S}$

$\mathrm{R}=\mathrm{H}, \mathrm{Ph}$

\section{Figure 3}

\section{Results and Discussion}

\section{Chemistry}

For the preparation of simple unsubstituted isopropanolamine core ( $\mathrm{R}=\mathrm{H}$ in figure 3 ), in consideration of our previous research, ${ }^{4}$ the synthetic route started from the commercially available bidentate electrophile $(S)$-glycidol 4 (Scheme 1). 
<smiles>COc1ccc(S(=O)(=O)OCC(O)CN(CC(C)C)S(=O)(=O)c2ccc(OC)cc2)cc1</smiles><smiles>[3H]CC(O)CN(CC(C)C)S(=O)(=O)c1ccc(OC)cc1</smiles><smiles>[X]c1ccc(OC(=O)NCC(O)CN(CC(C)C)S(=O)(=O)c2ccc(OC)cc2)cc1[Y]#N</smiles>

Scheme 1. Synthesis of inhibitors 10a-c: (a) $i$ - $\mathrm{BuNH}_{2}, i$-PrOH, rt, 24h (quant.); (b) 2 eq. 4methoxybenzenesulfonyl chloride, $\mathrm{Et}_{3} \mathrm{~N}, \mathrm{CH}_{2} \mathrm{Cl}_{2}, \mathrm{rt}, 24 \mathrm{~h}$; (c) $\mathrm{NaN}_{3}, \mathrm{DMF}$, reflux (80\% yield from 4); (d) $\mathrm{H}_{2}, \mathrm{Pd} / \mathrm{C} \mathrm{10 \% ,} \mathrm{EtOH,} \mathrm{rt,} \mathrm{4h;} \mathrm{(e)} \mathrm{5-hydroxyheteroarenes} \mathrm{9a-c,} \mathrm{p-nitrophenylchloroformiate,}$ $\mathrm{Et}_{3} \mathrm{~N}, \mathrm{DCM}, 1 \mathrm{~h}, \mathrm{rt}$; then 8, rt, 24h (10a, 74\%, 10b, 72\%, 10c 72\%).

(S)-Glycidol was first reacted with isobutylamine in isopropanol to achieve aminodiol $\mathbf{5}$, which was successfully treated with $p$-methoxybenzenesulfonyl chloride and triethylamine in $\operatorname{dry} \mathrm{CH}_{2} \mathrm{Cl}_{2}$ to obtain sulfamido-sulfonate 6. This compound underwent to nucleophilic displacement with $\mathrm{NaN}_{3}$, to give the sulfamidyl-azide $\mathbf{7}$, which was then reduced to amine $\mathbf{8}$ by catalytic hydrogenation. In the last step, the suitable heteroaryl-carbamoyl group was introduced by a reaction with different carbonates 11a-c, which were formed in situ from the corresponding 5-hydroxyheteroarene 9a-c and $p$-nitrophenylchloroformate. (Scheme 2)

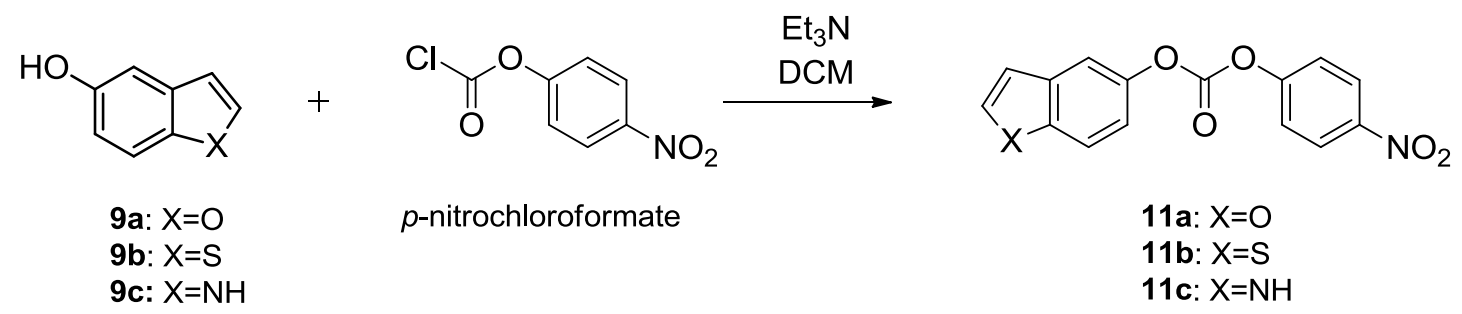

Scheme 2. Synthesis of intermediates 11a-c

While 5-hydroxyindole $\mathbf{9 c}$ is cheaply available, 5-hydroxybenzofuran 9a and 5hydroxybenzothiophene $\mathbf{9 b}$ had to be prepared, due to their high cost. Unfortunately, only few 
methods are reported in literature. ${ }^{6}$ In particular, those starting from 4-methoxyphenol 12a or 4methoxythiophenol 12b usually give low overall yield, due to the cyclization step. Hence, we successfully revisited such procedure, using bromodiethylacetal in the alkylation step and Amberlyst $-15^{7}$ in the subsequent cyclization/aromatization step. (Scheme 3).

By these modifications 5-methoxy-heteroarenes 14a-b were obtained in good yield (> 60\% in two steps from 12a-b). Demethylation of 14a-b afforded to desired 5-hydroxyheteroarenes 9a-b in high yield, making such three steps procedure the best one reported, in terms of overall yield (> 49\% yield from 12a-b).

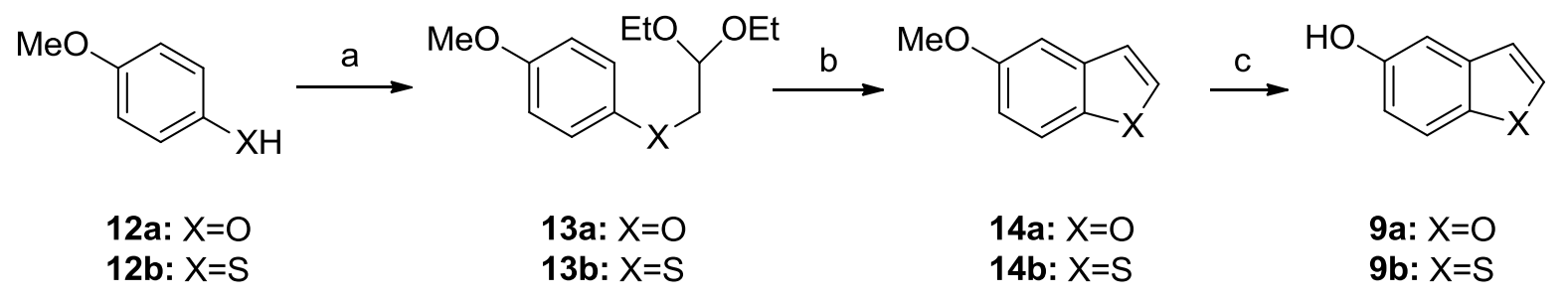

Scheme 3. Synthesis of heteroarenes 9a-b: (a) 4-methoxy(thio)phenol 12a or 12b, $\mathrm{BrCH}_{2} \mathrm{CH}(\mathrm{OEt})_{2}, \mathrm{Cs}_{2} \mathrm{CO}_{3}, \mathrm{MeCN}$, reflux, 40h (13a, 78\%; 13b, 81\%); (b) 12a-c, Amberlyst-15, chlorobenzene $120^{\circ} \mathrm{C}$, 3h (14a, 78\%; 14b, 75\%); (c) $\mathrm{BBr}_{3} \mathrm{SMe}_{2} 1 \mathrm{M}$ in $\mathrm{CH}_{2} \mathrm{Cl}_{2}$, chlorobenzene $120^{\circ} \mathrm{C}, 24 \mathrm{~h}(\mathbf{9 a}, 80 \% ; \mathbf{9 b}, 81 \%)$.

The preparation of benzyl substituted derivatives (with $\mathrm{R}=\mathrm{Bn}$ in structure A, figure 3) was even shorter, taking advantage of established chemistry ${ }^{8}$ and using homochiral $N$-Boc protected amino epoxide 15. The epoxide was firstly opened with iso-butylamine to afford the monoprotected diaminoalcohol 16 (scheme 4). Then, the $p$-methoxyphenylsulfonyl group was introduced and the $N$-Boc group efficiently displaced by TFA. The crude ammonium trifluoroacetate derivative was treated with $\mathrm{NEt}_{3}$, affording the free amine 18. From this common intermediate, we were easily able to achieve new inhibitors 19a-c by reaction of amine 18 with the in situ preformed carbonates 11a-c of the starting phenols 9a-c. 
15

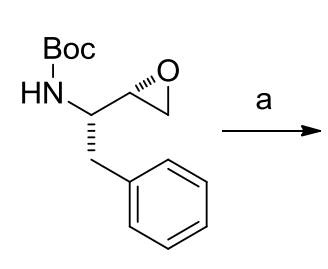

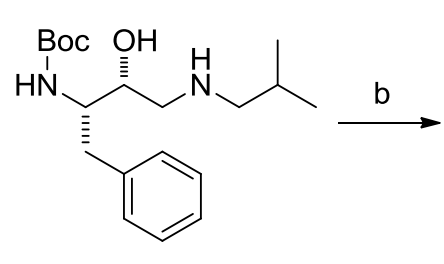

16<smiles>COc1ccc(S(=O)(=O)N(CC(C)C)C[C@H](O)[C@H](Cc2ccccc2)NC(=O)O)cc1</smiles>

17

c<smiles>[X]c1ccc2cc(OC(=O)N[C@@H](Cc3ccccc3)[C@H](O)CN(CC(C)C)S(=O)(=O)c3ccc(OC)cc3)ccc2c1</smiles>

19a: $X=0$

19b: $X=S$

19c: $X=\mathrm{NH}$

Scheme 4. Synthesis of inhibitors 19a-c: (a) $i-\mathrm{BuNH}_{2}, i-\mathrm{PrOH}, 60^{\circ} \mathrm{C}$, 4h (>99\% yield); (b) 4methoxybenzenesulfonyl chloride, $\mathrm{Et}_{3} \mathrm{~N}, \mathrm{CH}_{2} \mathrm{Cl}_{2}, \mathrm{rt}, 24 \mathrm{~h}$; (c) TFA/ $\mathrm{CH}_{2} \mathrm{Cl}_{2} 30 \%, \mathrm{rt}, 1 \mathrm{~h}$; then $\mathrm{Et}_{3} \mathrm{~N}$ (84\% yield from 16); (d) 5-hydroxyheteroarenes 9a-c, $p$-nitrophenylchloroformiate, $\mathrm{Et}_{3} \mathrm{~N}, \mathrm{CH}_{2} \mathrm{Cl}_{2}$, 1h, rt; then 18, rt, 24h (19a, 75\%; 19b, 71\%; 19c 70\%).

It is to be highlighted that this synthetic pathway appears very solid, high yielding and general, irrespective on the $N$-alkyl group, the sulfonamide or the type of heteroaryl moiety chosen. The easy access of common intermediates represents an open door to different target molecules with pharmacological activities even beyond the inhibition of HIV-protease. ${ }^{9}$

Biological assays were carried out on all the prepared compounds both in vitro and in mammalian cells, as described in the next section.

\section{In vitro activity}

$\mathrm{IC}_{50}$ values were obtained on recombinant wild type HIV protease (Table 1) by measuring the initial rates of hydrolysis of the fluorogenic substrate Abz-Thr-Ile-Nle-Phe(NO2)-Gln-Arg as previously reported ${ }^{5}$. 
Table 1. Biological data $\left(\mathrm{IC}_{50}, \mathrm{CC}_{50}\right.$ and Clearance) of the synthetized inhibitors

\begin{tabular}{|ccccc|}
\hline Entry & Structure & IC $_{\mathbf{5 0}}(\mathbf{n M})$ & $\mathbf{C C}_{\mathbf{5 0}}(\boldsymbol{\mu M})$ & $\begin{array}{c}\text { Clearance }(\boldsymbol{\mu L} / \mathbf{m i n} / \mathbf{m g} \text { protein): } \\
\text { a) human liver microsome } \\
\text { b) rat liver microsomes }\end{array}$ \\
\hline 1 & $\mathbf{1 0 a}$ & $15400 \pm 500$ & & $/$ \\
\hline 2 & $\mathbf{1 0 b}$ & $49 \pm 7$ & $>100$ & $/$ \\
\hline 3 & $\mathbf{1 0 c}$ & $13400 \pm 220$ & & a) 121 \\
\hline 4 & $\mathbf{1 9 a}$ & $\leq 0.6^{*}$ & $>100$ & b) 26.8 \\
\hline 5 & 19b & $10.8 \pm 1.2$ & n.d. & n.d. \\
\hline 6 & 19c & $\leq 0.6^{*}$ & 2.8 & a) 548 \\
& & & & b) 522 \\
\hline
\end{tabular}

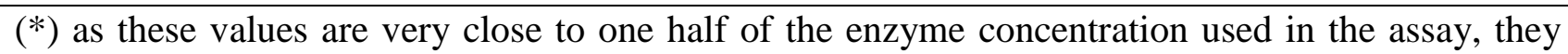
should be regarded as estimated upper limits.

As it can be seen, compounds $19 \mathrm{a}$ and $19 \mathrm{c}$ are the most powerful inhibitors on the list, their $\mathrm{IC}_{50}$ values being as less that $0.6 \mathrm{nM}$. Their activity is therefore higher than that of their corresponding amides, described in our previous work. ${ }^{5}$

On the other hand, when the benzyl side chain at P1' is lacking, as in compounds 10a-c, the activity is largely lost, with the exception of benzothienyl derivative 10b. Under this point of view, this series of carbamates behaves differently from the previous series of amides, where also the benzofurane derivative corresponding to $\mathbf{1 0 a}$ was found to inhibit the enzyme with an $\mathrm{IC}_{50}$ value of $1 \mathrm{nM}$.

In order to explain such results, we carried out a series of docking runs on carbamates 19a, 19c and 10a, 10c. The calculation was carried out with Autdock Vina. ${ }^{10}$ The best poses were further refined by MD runs, which were carried out with the Gromacs package. ${ }^{11}$

Despite the longer linker connecting the heteroaryl moiety with the core unit of the inhibitors, both 19a and 19c can interact very well with the $S 2$ ' subsite, and the number of favorable interactions is indeed the same obtained with the corresponding amides already described, Errore. L'origine riferimento non è stata trovata. as there is room enough in the site. Moreover, the benzofuran system of 19a could accept hydrogen bonding from Asp130 either at its side chain or at its backbone NH (Figure 4A, table 2). The lack of a methoxy group in comparison to the amides at the other side of the molecule has no effects on binding, most likely because this group was partly exposed to the solvent and not involved in interactions in the previous series of compounds. On the contrary, when the benzyl 
group is removed from the molecules as in 10a and 10c, two main docking solutions are found, but both fail to reach the maximum number of interactions attainable with the amides or with reference inhibitors as Amprenavir. In the first option, the heterocyclic side chain is still found inside S2', with similar interactions, but of course the $\mathrm{S} 1$ ' subsite is completely empty. The second solution is similar to that obtained in our previous work ${ }^{5}$ on the compounds lacking of the benzyl group, but this time the connecting chain is too long, and the aromatic system is largely exposed to the solvent outside the catalytic site of the enzyme, without recovering favorable interactions, as it can be clearly seen in the top view of Figure 4B and in table 2.

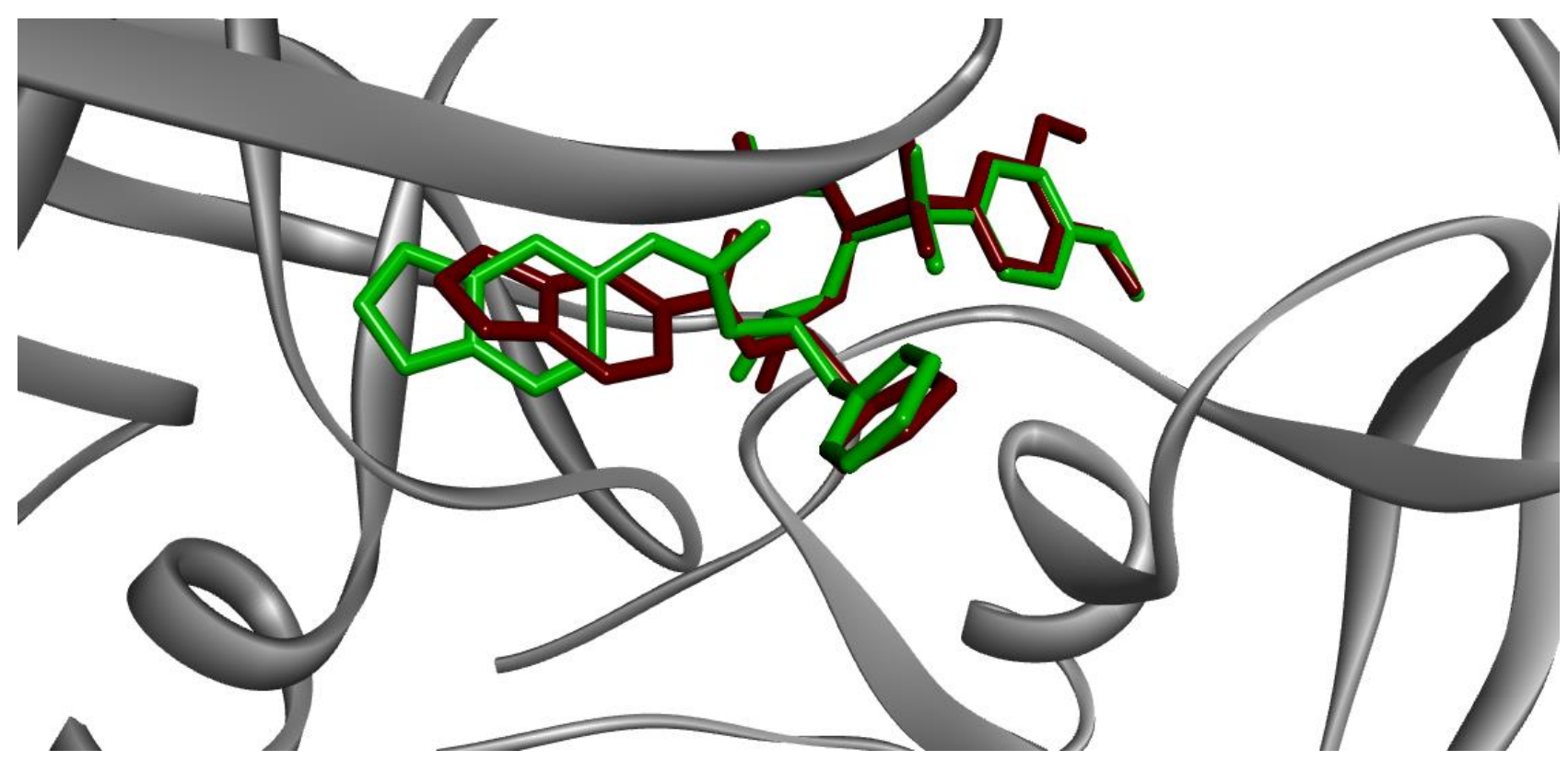

A

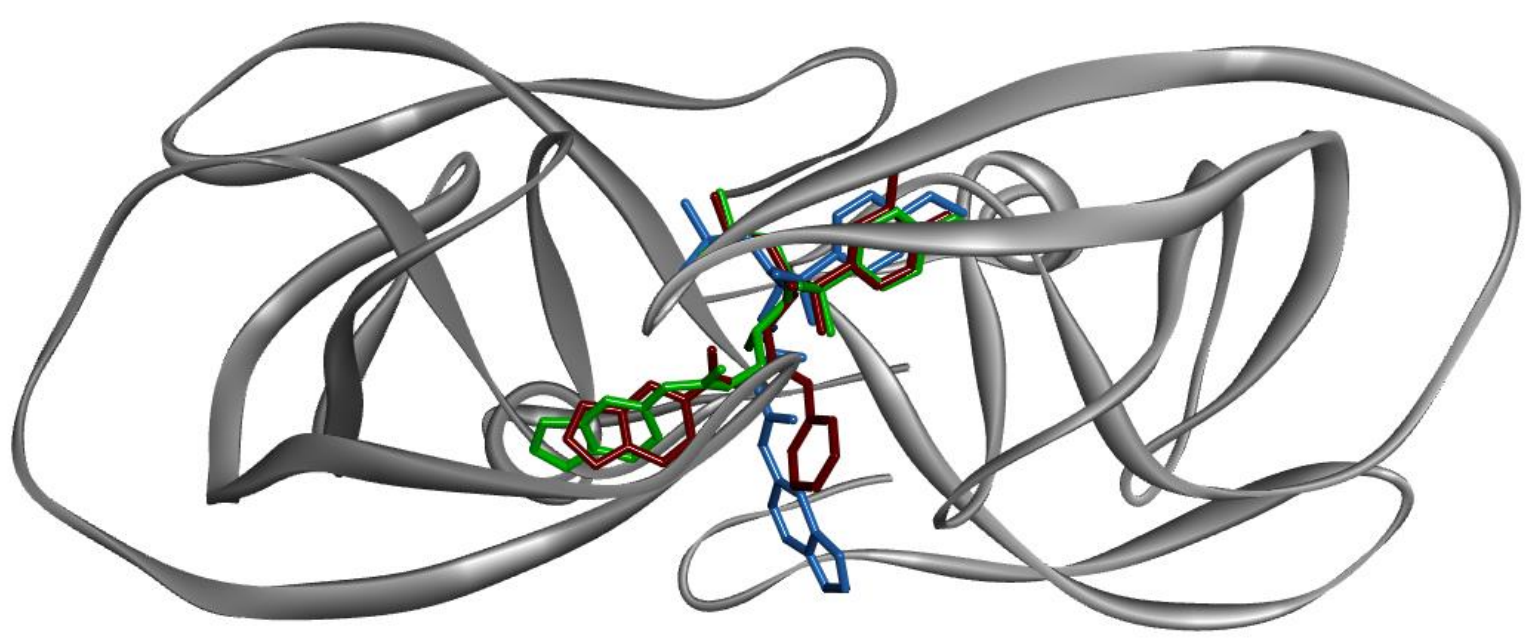


Figure 4. A: overlay of the optimized complex of HIV-protease with compound 19a (green) with that of corresponding benzofuryl amide (red). B: top view of the overlay of the best docking solutions for compound 10a (green and blue) with the corresponding amide (red).

Table 2. Number of favorable contacts established by the inhibitors at the $\mathrm{S} 1$ ' and $\mathrm{S} 2$ ' of the protease.

(1)

Provided the presence of a new carbamoyl moiety, which makes these new compounds completely non peptidic, a preliminary study on the clearance was realized, in particular on inhibitors 19a and 19c. It is well known that all HIV-1 Pr inhibitors which are currently on the market, except Ritonavir, undergo rapid degradation by cytochrome CYP3A and therefore require Ritonavir during their administration, to slow down their disposal. The tests were performed using human liver microsomes in the absence of Ritonavir as a booster. The results are reported in previous Table 1. As it can be seen the metabolic stability data of 19a are generally in line with those reported in the literature $^{12}$ on the commercially available inhibitors. In fact, this new compound presents an intrinsic in vitro clearance ranging from 26.8 to $121 \mu \mathrm{L} / \mathrm{min} / \mathrm{mg}$. On the other hand the intrinsic clearance shown by 19c was comparable only to that reported for Darunavir (from 522 to $548 \mu \mathrm{L} /$ $\min / \mathrm{mg}$ ), making this compound very promising. 
Biology

All these new carbamate molecules were evaluated in their ability to inhibit the HIV-1 protease in mammalian cells, using a method developed by Lindsten et al. ${ }^{13}$ and already used in our previous work. ${ }^{5}$ Briefly, the expression of the precursor of HIV-1 protease bounded to green fluorescent protein (GFP) is toxic upon autocatalytic cleavage, determining the disappearance of the fluorescent signal. In the presence of a molecule with inhibitory activity, the signal due to the intact GFP-PR chimera becomes detectable and useful to monitor the in vivo inhibition of the enzyme.

To use properly the molecules, we initially evaluated their possible cytotoxicity towards HEK293 cells using the MTT dose-dependent viability assay. Our results determined a value of $\mathrm{CC}_{50}>60$ $\mu \mathrm{M}$ for all the inhibitors, after 24 hours of exposure to 10a-c and 19a-c molecules (data are reported in Supplementary Materials). Therefore, the values of inhibitors concentrations used in all subsequent assays did not compromise cell viability.

The quantitative analysis of the fluorescence signal given by the GFP-PR chimera, possibly inhibited by the 10a-c and 19a-c molecules, was performed by FACS analysis of the transfected cells, while the qualitative evaluation was performed by fluorescence microscopy. In detail, a weak background signal was detected in cells transfected with GFP-PR not treated with any inhibitor (Figure 5A, CTRL). 
A

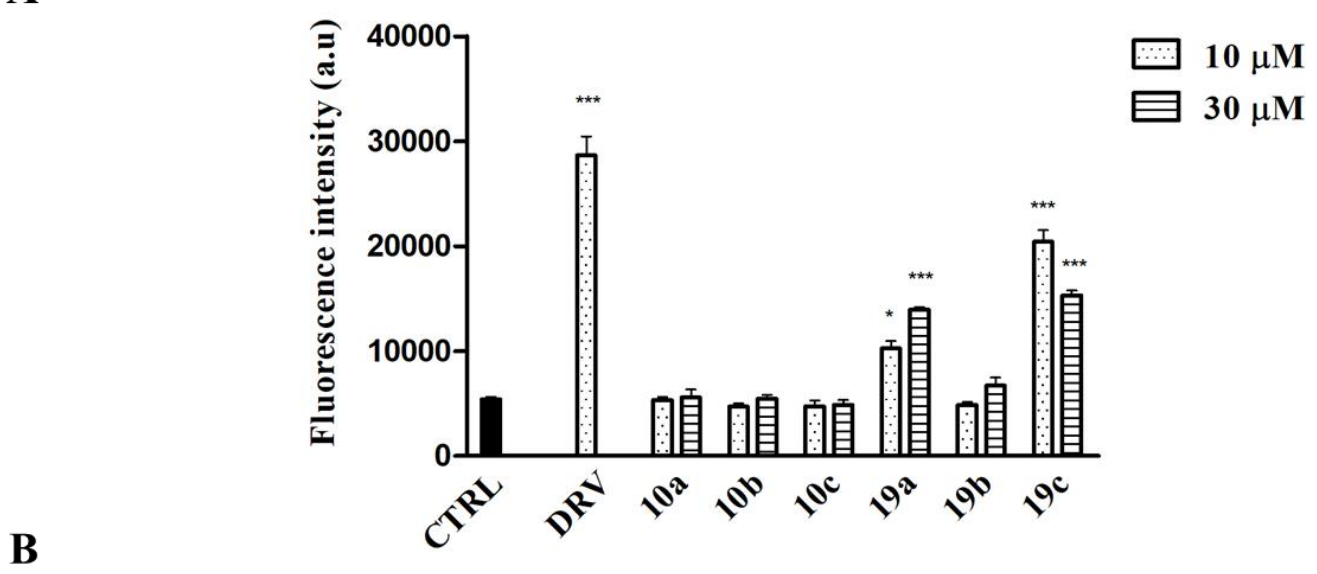

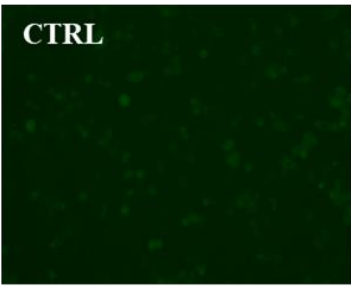
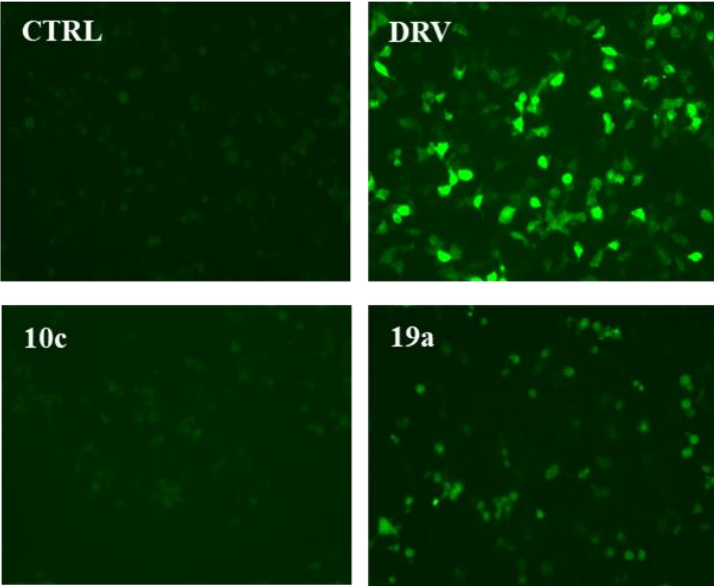

\section{9 a}

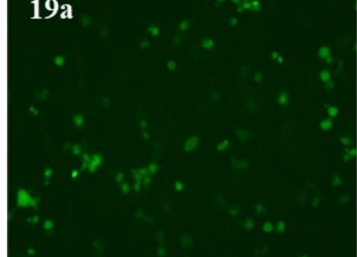

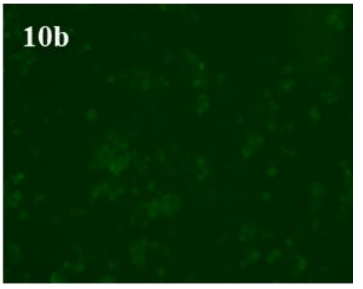
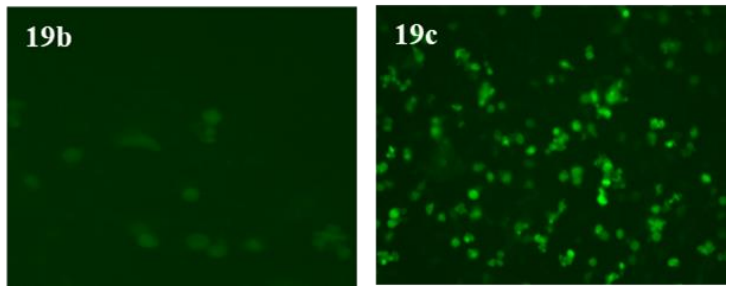

Figure 5. GFP-PR expression fluorescence analysis. A) FACS analysis of HEK293 cells transiently transfected with pcDNA3/GFP-PR and treated for $24 \mathrm{~h}$ with HIV-1 protease inhibitors at indicated concentrations. CTRL stands for not inhibited HIV-1 protease expressing cells. Data are expressed as means \pm standard error (SE) of three replicates from three independent experiments and were analyzed by one-way ANOVA followed by Dunnett's post hoc test using GraphPad Prism 7 software. ${ }^{*} p<0.05$, ***p<0.001. B) HEK293 cells expressing GFP-PR fusion protein were visualized by fluorescence microscopy after incubation with $30 \mu \mathrm{M}$ of each inhibitor (10 $\mu \mathrm{M}$ for 19a) for $24 \mathrm{~h}$. CTRL stands for not inhibited HIV-1 protease expressing cells and DRV indicates $10 \mu M$ Darunavir treatment (positive control). Images (40x magnification) are representative of three independent experiments.

In contrast, cells transfected and treated with the commercial inhibitor Darunavir (DRV) showed a strong fluorescence signal, highlighting an optimal inhibition of the viral enzyme. Cells transfected and treated with each of the putative inhibitors showed a poor fluorescence signal relatively to the molecules 10a, 10b, 10c and 19b, evaluated both at $10 \mu \mathrm{M}$ and at $30 \mu \mathrm{M}$ of concentration (Figure 5A), while a more than appreciable fluorescence signals were detected for the molecules 19a and 19c. Of note, 19a molecule showed best activity at concentration of $30 \mu \mathrm{M}$, whereas 19c compound had best inhibition activity at $10 \mu \mathrm{M}$. These results have been confirmed by qualitative analysis of fluorescence intensity, performed at the most active concentrations of the inhibitors (Figure 5B).

To evaluate the ability of the 19a and 19c molecules to be active also in the presence of some of the most common clinically significant drug-resistance mutations, we performed mutagenesis experiments on the wild type GFP-PR vector, providing the site-specific mutations V32I and 
V82A. ${ }^{14}$ As shown in figure $6 \mathrm{~A}$ e $6 \mathrm{~B}$, the inhibitory activity of molecules $19 \mathrm{a}$ and $\mathbf{1 9 c}$ towards both variants of the HIV-1 protease is maintained almost unchanged compared to that shown against the wild type protease, suggesting that these mutations do not affect in any way their activity.
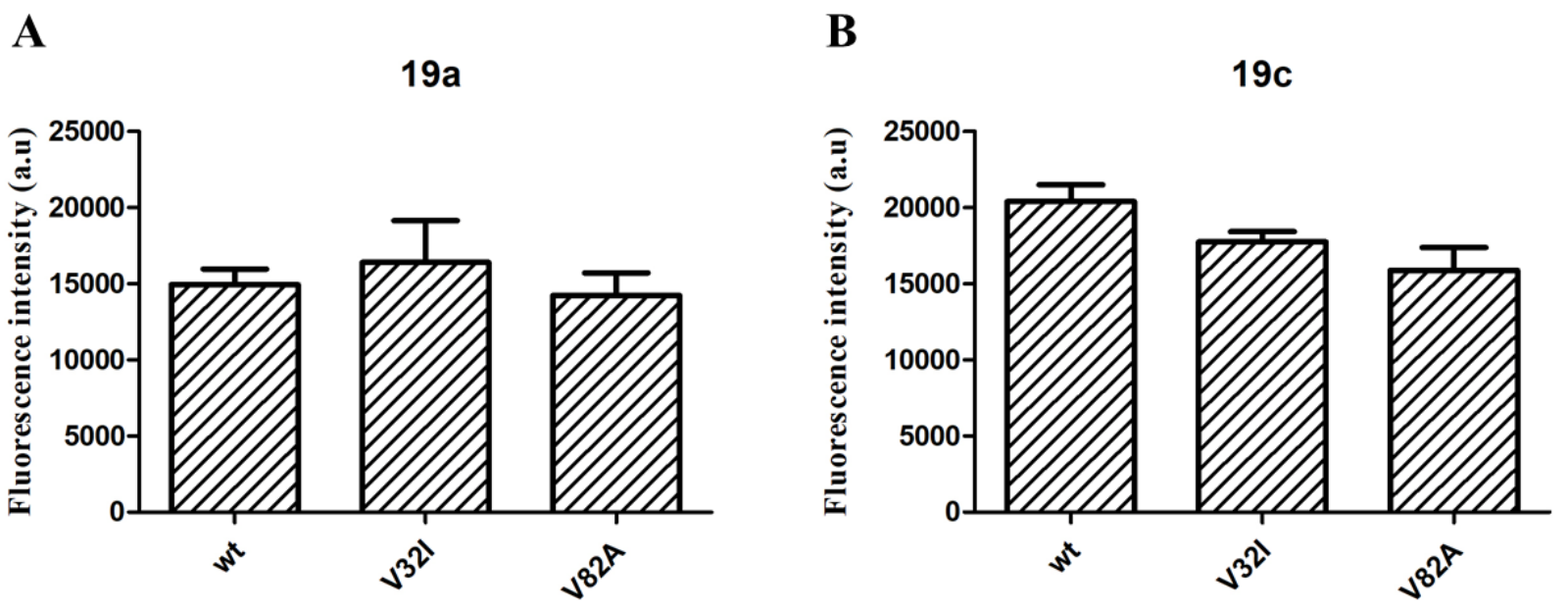

Figure 6. Evaluation of HIV-1 protease variants inhibition. FACS analysis of HEK293 cells transiently transfected with pcDNA3/GFP-PR-V32I and with pcDNA3/GFP-PR-V82A and treated for $24 h$ with HIV-1 protease inhibitors A) $19 a$ and B) $19 c$, at $30 \mu \mathrm{M}$ and $10 \mu \mathrm{M}$, respectively. Data are expressed as means \pm standard error (SE) of three replicates from three independent experiments.

\section{Conclusion}

In conclusion, our results showed that some of the newly synthesized molecules have inhibitory activity against HIV-1 protease in mammalian cells, confirming, moreover, the data obtained in in vitro assays. Although they still are less active than the commercial inhibitor Darunavir, however, maintain this activity also towards variants of the protease.

Furthermore, we can firstly highlighted that the presence of carbamate function makes these new compounds metabolically as stable as the most currently used inhibitors. In particular, benzofuran is apparently the heterocycle which confers greater metabolic stability.

Considering the excellent biological activity, the very low cytotoxicity and the good clearance profile, compounds 19a and 19c represent very promising molecules. Being on track to counteract drug resistance encourages us to continue our studies, optimizing the chemical structure of HIV protease inhibitors to improve their properties as much as possible.

\section{Experimental section}

\section{Chemistry}

Preparative chromatography was carried out on Merck silica gel (0.063-0.200 mm particle size) by progressive elution with opportune solvent mixtures. ${ }^{1} \mathrm{H}$ and ${ }^{13} \mathrm{C}$ NMR spectra were normally 
carried out in $\mathrm{CDCl}_{3}$ solutions on a VARIAN INOVA $500 \mathrm{MHz}$ or Bruker $400 \mathrm{MHz}$ and referenced to $\mathrm{CDCl}_{3}$. Mass spectra were obtained with a Hewlett-Packard 5971 mass-selective detector on a Hewlett-Packard 5890 gas chromatograph [(OV-1 capillary column between 70 and $250{ }^{\circ} \mathrm{C}\left(20{ }^{\circ} \mathrm{C}\right.$ $\left.\left.\min ^{-1}\right)\right]$. The optical purity was evaluated by using a polarimeter JASCO Mod Dip-370. $\mathrm{CH}_{2} \mathrm{Cl}_{2}$ was dried by distillation over anhydrous $\mathrm{CaCl}_{2}$ in inert atmosphere. Dry THF and DMF were commercially available.

\section{(2R)-3-Isobutylamino-propane-1,2-diol (5)}

$i$ - $\mathrm{BuNH}_{2}(8.0 \mathrm{~mL}, 80 \mathrm{mmol})$ was added to a stirred solution of $(S)$-glycidol $4(0.308 \mathrm{~g}, 4.0 \mathrm{mmol})$ in $i$-PrOH $(20 \mathrm{~mL})$. The mixture was stirred at room temperature and after $24 \mathrm{~h}$. Then the solvent and the excess of $i$ - $\mathrm{BuNH}_{2}$ were removed under reduced pressure. The aminodiol $\mathbf{5}$ was obtained as oil in quantitative yield. ${ }^{1} \mathrm{H}$ and ${ }^{13} \mathrm{C}$ NMR spectra were consistent to literature data. ${ }^{4 a}$

\section{(2R)-4-Methoxy-benzenesulfonic acid 2-hydroxy-3-[isobutyl-(4-methoxy-benzenesulfonyl)-} amino]-propyl ester (6).

To a stirred solution of aminodiol $5(0.115 \mathrm{~g}, 0.78 \mathrm{mmol})$ in anhydrous $\mathrm{CH}_{2} \mathrm{Cl}_{2}(40 \mathrm{~mL}), \mathrm{Et}_{3} \mathrm{~N}(0.28$ $\mathrm{mL}, 2.02 \mathrm{mmol})$ and 4-methoxybenzenesulfonyl chloride $(0.384 \mathrm{~g}, 1.86 \mathrm{mmol})$ were added at room temperature and under $\mathrm{Ar}$ atmosphere. After $24 \mathrm{~h}$ the reaction was quenched with $\mathrm{H}_{2} \mathrm{SO}_{4} 5 \%$ solution. Organic phase was washed adding saturated aqueous $\mathrm{NaHCO}_{3}$ solution and brine. The organic phases were collected, dried over $\mathrm{Na}_{2} \mathrm{SO}_{4}$, filtered and concentrated in vacuo. The crude containing compound $\mathbf{6}$ was used in the subsequent reaction without any purification.

\section{(2S)- $N$-(3-Azido-2-hydroxy-propyl)- $N$-isobutyl-4-methoxy-benzenesulfonamide (7).}

The product $6(0.78 \mathrm{mmol})$ was dissolved in anhydrous DMF $(10 \mathrm{~mL})$ and $\mathrm{NaN}_{3}(0.104 \mathrm{~g}, 1.60$ mmol) was added at room temperarure and under Ar atmosphere. The reaction mixture was warmed at reflux and kept stirring for $4 \mathrm{~h}$. The reaction was then quenched by adding $\mathrm{H}_{2} \mathrm{O}(20 \mathrm{~mL})$. The mixture was then extracted with $\mathrm{CH}_{2} \mathrm{Cl}_{2}(3 \times 30 \mathrm{~mL})$ and the organic layer was dried with anhydrous $\mathrm{Na}_{2} \mathrm{SO}_{4}$, filtered and concentrated in vacuo. The crude was purified on silica gel $\left(\mathrm{CH}_{2} \mathrm{Cl}_{2} / \mathrm{EtOAc}\right.$ 98:2) and compound 7 was isolated as brown oil ( $0.219 \mathrm{~g}, 82 \%$ from 5).

$[\alpha]_{\mathrm{D}}^{20}=-8.0\left(\mathrm{c} 0.5, \mathrm{CH}_{2} \mathrm{Cl}_{2}\right)$

${ }^{1} \mathrm{H}$ NMR (400 MHz, $\left.\mathrm{CDCl}_{3}\right) \delta(\mathrm{ppm}): 7.73(\mathrm{~d}, J=6.8 \mathrm{~Hz}, 2 \mathrm{H}), 6.90(\mathrm{~d}, J=6.8 \mathrm{~Hz}, 2 \mathrm{H}), 4.03-3.92$ $(\mathrm{m}, 1 \mathrm{H}), 3.86(\mathrm{~s}, 3 \mathrm{H}), 3.41-3.23(\mathrm{~m}, 3 \mathrm{H}), 3.18-2.88(\mathrm{~m}, 4 \mathrm{H}), 1.95-1.88(\mathrm{~m}, 1 \mathrm{H}), 0.92(\mathrm{~d}, J=5.6 \mathrm{~Hz}$, $3 \mathrm{H}), 0.85(\mathrm{~d}, J=5.6 \mathrm{~Hz}, 3 \mathrm{H})$. 
MS (m/z): $343\left(\mathrm{MH}^{+}\right)$. Anal. Calcd. for $\mathrm{C}_{14} \mathrm{H}_{22} \mathrm{~N}_{4} \mathrm{O}_{4} \mathrm{~S}: \mathrm{C}, 49.11 ; \mathrm{H}, 6.48 ; \mathrm{N}, 16.36 ; \mathrm{O}, 18.69 ; \mathrm{S}$, 9.36. Found C, 49.0; H, 6.5; N, 16.4; S, 9.4.

\section{(2S)- $N$-(3-Amino-2-hydroxy-propyl)- $N$-isobutyl-4-methoxy-benzenesulfonamide (8).}

$\mathrm{Pd} / \mathrm{C} 10 \%(0.026 \mathrm{~g})$ was added to a solution of compound $7(0.171 \mathrm{~g}, 0.50 \mathrm{mmol})$ in EtOH $(10 \mathrm{~mL})$. The reaction mixture was stirred under $\mathrm{H}_{2}$ atmosphere at room temperature. After $4 \mathrm{~h}$ the reaction mixture was fluxed with Ar, filtered on a Celite path, washed with EtOH and concentrated in vacuo. The crude containing compound $\mathbf{8}$ was used in the subsequent reaction without any purification. $[\alpha]^{20}{ }_{D}=-6.0\left(\mathrm{c} 0.5, \mathrm{CH}_{2} \mathrm{Cl}_{2}\right)$

${ }^{1} \mathrm{H}$ NMR (400 MHz, $\left.\mathrm{CDCl}_{3}\right) \delta(\mathrm{ppm}): 7.76(\mathrm{~d}, J=8.4 \mathrm{~Hz}, 2 \mathrm{H}), 6.99$ (d, $\left.J=8.4 \mathrm{~Hz}, 2 \mathrm{H}\right), 4.70$ (s, $2 \mathrm{H}), 4.10(\mathrm{~s}, 1 \mathrm{H}), 3.88(\mathrm{~s}, 3 \mathrm{H}), 3.79(\mathrm{~m}, 1 \mathrm{H}), 3.38-3.36(\mathrm{~m}, 2 \mathrm{H}), 3.10-2.80(\mathrm{~m}, 2 \mathrm{H}), 2.74(\mathrm{~m}, 2 \mathrm{H})$, $1.64(\mathrm{~m}, 1 \mathrm{H}), 0.91(\mathrm{~d}, J=6.8 \mathrm{~Hz}, 3 \mathrm{H}), 0.84(\mathrm{~d}, J=6.8 \mathrm{~Hz}, 3 \mathrm{H})$.

MS (m/z): $317\left(\mathrm{MH}^{+}\right)$. Anal. Calcd. for $\mathrm{C}_{14} \mathrm{H}_{24} \mathrm{~N}_{2} \mathrm{O}_{4} \mathrm{~S}: \mathrm{C}, 53.14 ; \mathrm{H}, 7.65 ; \mathrm{N}, 8.85 ; \mathrm{O}, 20.23 ; \mathrm{S}$, 10.13. Found C, 53.0; H, 7.4; N, 8.7; S, 9.8.

\section{Preparation of carbamates: general procedure.}

$\mathrm{Et}_{3} \mathrm{~N}(0.033 \mathrm{~mL}, 0.24 \mathrm{mmol})$ and $p$-nitrophenylchloroformiate $(0.048 \mathrm{~g}, 0.24 \mathrm{mmol})$ were added to a solution of 5-hydroxyheteroarenes 9a-c $(0.24 \mathrm{mmol})$ in anhydrous $\mathrm{CH}_{2} \mathrm{Cl}_{2}(1 \mathrm{~mL})$, under $\mathrm{Ar}$ atmosphere. The mixture was kept stirring at room temperature for $1 \mathrm{~h}$ to afford intermediates 11ac; then amine 8 (or 18) $(0.20 \mathrm{mmol}$ ) was added and the mixture was kept stirring for $24 \mathrm{~h}$. The solvent was evaporated and the crude compounds were purified on silica gel (EP/EtOAc 97:3), affording to compounds 10a-c (or 19a-c).

\section{(2S)-\{2-Hydroxy-3-[isobutyl-(4-methoxy-benzenesulfonyl)-amino]-propyl\}-carbamic}

acid benzofuran-5-yl ester (10a).

The product 10a was obtained as white solid (74\% yield). $[\alpha]^{20}{ }_{\mathrm{D}}=+10.7\left(\mathrm{c} 0.5, \mathrm{CH}_{2} \mathrm{Cl}_{2}\right) .{ }^{1} \mathrm{H}$ NMR $\left(500 \mathrm{MHz}, \mathrm{CDCl}_{3}\right) \delta(\mathrm{ppm}): 7.75(\mathrm{~d}, J=8.8 \mathrm{~Hz}, 2 \mathrm{H}), 7.64(\mathrm{~d}, J=2.0 \mathrm{~Hz}, 1 \mathrm{H}), 7.46(\mathrm{~d}, J=8.8 \mathrm{~Hz}$, $1 \mathrm{H}), 7.35(\mathrm{~d}, J=2.0 \mathrm{~Hz}, 1 \mathrm{H}), 7.04\left(\mathrm{dd}, J_{1}=8.8 \mathrm{~Hz}, J_{2}=2.0 \mathrm{~Hz}, 1 \mathrm{H}\right), 6.99(\mathrm{~d}, J=8.8 \mathrm{~Hz}, 2 \mathrm{H}), 6.74$ (brs, 1H), $3.99(\mathrm{bs}, 1 \mathrm{H}), 3.86(\mathrm{~s}, 3 \mathrm{H}), 3.60(\mathrm{~m}, 2 \mathrm{H}), 3.35(\mathrm{~m}, 1 \mathrm{H}), 3.14$ (A of ABX system, $J_{\mathrm{AB}}=$ $\left.15.1 \mathrm{~Hz}, J_{\mathrm{AX}}=4.8 \mathrm{~Hz}, 1 \mathrm{H}\right), 3.04\left(\mathrm{~B}\right.$ of $\mathrm{ABX}$ system, $\left.J_{\mathrm{AB}}=15.1 \mathrm{~Hz}, J_{\mathrm{BX}}=7.3 \mathrm{~Hz}, 1 \mathrm{H}\right), 2.90(\mathrm{~d}, J=$ $7.8 \mathrm{~Hz}, 2 \mathrm{H}), 1.88(\mathrm{~m}, 1 \mathrm{H}), 0.93\left(\mathrm{~A}\right.$ of $\mathrm{AB}$ system, $\left.J_{\mathrm{AB}}=6.8 \mathrm{~Hz}, 3 \mathrm{H}\right), 0.92\left(\mathrm{~B}\right.$ of $\mathrm{AB}$ system, $J_{\mathrm{AB}}=$ $6.8 \mathrm{~Hz}, 3 \mathrm{H}) .{ }^{13} \mathrm{C} \mathrm{NMR}\left(125 \mathrm{MHz}, \mathrm{CDCl}_{3}\right) \delta(\mathrm{ppm}): 163.1,156.5,152.4,146.5,146.3,146.1,129.6$, 129.6, 129.4, 127.9, 118.2, 114.4, 113.7, 111.6, 106.8, 69.9, 59.1, 55.5, 53.1, 44.1, 27.19, 20.1, 
19.8. MS $(m / z): 477\left(\mathrm{MH}^{+}\right)$. Anal. Calcd for $\mathrm{C}_{23} \mathrm{H}_{28} \mathrm{~N}_{2} \mathrm{O}_{7} \mathrm{~S}: \mathrm{C}, 57.97 ; \mathrm{H}, 5.92 ; \mathrm{N}, 5.88 ; \mathrm{O}, 23.50 ; \mathrm{S}$, 6.73. Found C, 57.8; H, 5.7; N, 5.9; S, 6.6.

(2S)-\{2-Hydroxy-3-[isobutyl-(4-methoxy-benzenesulfonyl)-amino]-propyl\}-carbamic

acid benzo[b]thiophen-5-yl ester (10b).

The product $10 \mathrm{~b}$ was obtained as white solid $\left(72 \%\right.$ yield). $[\alpha]_{\mathrm{D}}^{20}=4.5$ (c $\left.0.5, \mathrm{CH}_{2} \mathrm{Cl}_{2}\right) .{ }^{1} \mathrm{H}$ NMR $\left(500 \mathrm{MHz}, \mathrm{CDCl}_{3}\right) \delta(\mathrm{ppm}): 7.84(\mathrm{~d}, J=8.6 \mathrm{~Hz}, 1 \mathrm{H}), 7.76(\mathrm{~d}, J=8.8 \mathrm{~Hz}, 2 \mathrm{H}), 7.59(\mathrm{~d}, J=2.1 \mathrm{~Hz}$, $1 \mathrm{H}), 7.49(\mathrm{~d}, J=5.4 \mathrm{~Hz}, 1 \mathrm{H}), 7.29(\mathrm{~d}, J=5.4 \mathrm{~Hz}, 1 \mathrm{H}), 7.13\left(\mathrm{dd}, J_{1}=8.8 \mathrm{~Hz}, J_{2}=2.1 \mathrm{~Hz}, 1 \mathrm{H}\right), 6.99$ (d, $J=8.8 \mathrm{~Hz}, 2 \mathrm{H}), 5.81$ (bs, 1H), 4.01 (bs, 1H), 3.87 (s, 3H), $3.61(\mathrm{~m}, 2 \mathrm{H}), 3.36(\mathrm{~m}, 1 \mathrm{H}), 3.14$ (A of $\mathrm{ABX}$ system, $\left.J_{\mathrm{AB}}=15.1 \mathrm{~Hz}, J_{\mathrm{AX}}=4.9 \mathrm{~Hz}, 1 \mathrm{H}\right), 3.05\left(\mathrm{~B}\right.$ of $\mathrm{ABX}$ system, $J_{\mathrm{AB}}=15.1 \mathrm{~Hz}, J_{\mathrm{BX}}=$ $7.2 \mathrm{~Hz}, 1 \mathrm{H}), 2.90(\mathrm{~d}, J=7.9 \mathrm{~Hz}, 2 \mathrm{H}), 1.89(\mathrm{~m}, 1 \mathrm{H}), 1.63(\mathrm{bs}, 1 \mathrm{H}), 0.93$ (A of AB system, $J_{\mathrm{AB}}=6.8$ $\mathrm{Hz}, 3 \mathrm{H}), 0.92\left(\mathrm{~B}\right.$ of $\mathrm{AB}$ system, $\left.J_{\mathrm{AB}}=6.8 \mathrm{~Hz}, 3 \mathrm{H}\right) .{ }^{13} \mathrm{C} \mathrm{NMR}\left(125 \mathrm{MHz}, \mathrm{CDCl}_{3}\right) \delta(\mathrm{ppm}): 163.1$, 156.3, 148.3, 140.3, 136.7, 129.7, 129.5, 128.1, 123.7, 122.9, 118.7, 115.9, 114.4, 69.9, 59.1, 55.6, 53.2, 44.2, 27.4, 20.1.MS (m/z): $493\left(\mathrm{MH}^{+}\right)$. Anal. Calcd for $\mathrm{C}_{23} \mathrm{H}_{28} \mathrm{~N}_{2} \mathrm{O}_{6} \mathrm{~S}_{2}: \mathrm{C}, 56.08 ; \mathrm{H}, 5.73 ; \mathrm{N}$, 5.69; O, 19.49; S, 13.02. Found C, 56.2; H, 5.5; N, 5.7; S, 13.2.

(2S)-\{2-Hydroxy-3-[isobutyl-(4-methoxy-benzenesulfonyl)-amino]-propyl\}-carbamic acid $1 \mathrm{H}$ indol-5-yl ester (10c).

The product 10c was obtained as white solid $\left(72 \%\right.$ yield). $[\alpha]^{20}{ }_{\mathrm{D}}=32.4\left(\mathrm{c} 0.5, \mathrm{CH}_{2} \mathrm{Cl}_{2}\right) .{ }^{1} \mathrm{H} \mathrm{NMR}$ $\left(500 \mathrm{MHz}, \mathrm{CDCl}_{3}\right) \delta(\mathrm{ppm}): 8.32$ (bs, 1H), $7.76(\mathrm{~d}, J=8.6 \mathrm{~Hz}, 2 \mathrm{H}), 7.37$ (bs, 1H), $7.32(\mathrm{~d}, J=8.5$ $\mathrm{Hz}, 1 \mathrm{H}), 7.22$ (bs, 1H), 7.00 (d, $J=8.6 \mathrm{~Hz}, 2 \mathrm{H}), 6.95$ (d, J=8.5 Hz, 1H), 6.52 (bs, 1H), 5.76 (bs, $1 \mathrm{H}), 3.98(\mathrm{bs}, 1 \mathrm{H}), 3.86(\mathrm{~s}, 3 \mathrm{H}), 3.60(\mathrm{~m}, 1 \mathrm{H}), 3.35(\mathrm{~m}, 1 \mathrm{H}), 3.16\left(\mathrm{~A}\right.$ of $\mathrm{ABX}$ system, $J_{\mathrm{AB}}=15.1$ $\left.\mathrm{Hz}, J_{\mathrm{AX}}=4.9 \mathrm{~Hz}, 1 \mathrm{H}\right), 3.04\left(\mathrm{~B}\right.$ of $\mathrm{ABX}$ system, $\left.J_{\mathrm{AB}}=15.1 \mathrm{~Hz}, J_{\mathrm{AX}}=7.4 \mathrm{~Hz}, 1 \mathrm{H}\right), 2.91(\mathrm{~d}, J=7.4$ $\mathrm{Hz}, 2 \mathrm{H}), 2.18(\mathrm{~s}, 3 \mathrm{H}), 1.89(\mathrm{~m}, 1 \mathrm{H}), 0.94\left(\mathrm{~A}\right.$ of $\mathrm{AB}$ system, $\left.J_{\mathrm{AB}}=5.9 \mathrm{~Hz}, 3 \mathrm{H}\right), 0.92(\mathrm{~B}$ of $\mathrm{AB}$ system, $\left.J_{\mathrm{AB}}=5.9 \mathrm{~Hz}, 3 \mathrm{H}\right) .{ }^{13} \mathrm{C} \mathrm{NMR}\left(100 \mathrm{MHz}, \mathrm{CDCl}_{3}\right) \delta(\mathrm{ppm}): 163.1,157.1,144.6,133.6,129.7$, $129.5,128.1,125.5,116.3,114.4,112.7,111.3,102.9,70.0,59.1,55.6,53.2,44.2,27.4,20.0$.

MS (m/z): $476\left(\mathrm{MH}^{+}\right)$. Anal. Calcd for $\mathrm{C}_{23} \mathrm{H}_{29} \mathrm{~N}_{3} \mathrm{O}_{6} \mathrm{~S}: \mathrm{C}, 58.09 ; \mathrm{H}, 6.15 ; \mathrm{N}, 8.84 ; \mathrm{O}, 20.19 ; \mathrm{S}, 6.74$. Found C, 58.2; H, 6.2; N, 8.9; S, 6.7.

\section{$(1 R, 2 S)$ - (1-Benzyl-2-hydroxy-3-isobutylamino-propyl)-carbamic acid tert-butyl ester (16)}

$i$-BuNH${ }_{2}(8.0 \mathrm{~mL}, 80 \mathrm{mmol})$ was added to a stirred solution of (2S,3S)-1,2-epoxy-3-(Boc-amino)-4phenylbutane $15(1.053 \mathrm{~g}, 4.0 \mathrm{mmol})$ in $i-\mathrm{PrOH}(20 \mathrm{~mL})$. The mixture was warmed at $60^{\circ} \mathrm{C}$. After 6h the solvent and the excess of $i-\mathrm{BuNH}_{2}$ were removed under reduced pressure. The product 16 
was obtained as white solid in quantitative yield. ${ }^{1} \mathrm{H}$ and ${ }^{13} \mathrm{C}$ NMR spectra were consistent to literature data. ${ }^{8}$

\section{(1S,2R)-\{1-Benzyl-2-hydroxy-3-[iso-butyl-(4-methoxy-benzenesulfonyl)-amino]-propyl\}- carbamic acid tert-butyl ester (17).}

To a stirred solution of aminoalcohol $16(0.262 \mathrm{~g}, 0.78 \mathrm{mmol})$ in anhydrous $\mathrm{CH}_{2} \mathrm{Cl}_{2}(40 \mathrm{~mL}), \mathrm{Et}_{3} \mathrm{~N}$ $(0.28 \mathrm{~mL}, 2.02 \mathrm{mmol})$ and 4-methoxybenzenesulfonyl chloride $(0.192 \mathrm{~g}, 0.93 \mathrm{mmol})$ were added at room temperature and under Ar atmosphere. After $24 \mathrm{~h}$ the reaction was quenched with $5 \%$ aqueous $\mathrm{H}_{2} \mathrm{SO}_{4}$ solution. The organic layer was washed adding saturated aqueous $\mathrm{NaHCO}_{3}$ solution and brine. The organic phases collected were dried over $\mathrm{Na}_{2} \mathrm{SO}_{4}$, filtered and concentrated in vacuo. The crude was purified on silica gel $\left(\mathrm{CH}_{2} \mathrm{Cl}_{2} / \mathrm{EtOAc}\right.$ 98:2) and compound $\mathbf{1 7}$ was isolated as white solid. ${ }^{1} \mathrm{H}$ and ${ }^{13} \mathrm{C}$ NMR spectra were consistent to literature data. ${ }^{8}$

\section{$(2 R, 3 S) \quad N$-(3-Amino-2-hydroxy-4-phenyl-butyl)- $N$-isobutyl-4-methoxy-benzenesulfonamide} (18).

To a stirred solution of $17(0.395 \mathrm{~g}, 0.78 \mathrm{mmol})$ in anhydrous $\mathrm{CH}_{2} \mathrm{Cl}_{2}(29 \mathrm{~mL})$, trifluoroacetic acid $(13 \mathrm{~mL})$ was added at room temperature. After $1 \mathrm{~h}$ the reaction mixture was concentrated, treated with toluene $(3 \times 20 \mathrm{~mL})$ and evaporated under vacuum. The crude was purified on silica gel $\left(\mathrm{CHCl}_{3} / \mathrm{CH}_{3} \mathrm{OH}=9: 1\right)$ and the product 18 was obtained as white solid in $84 \%$ yield.

${ }^{1} \mathrm{H}$ and ${ }^{13} \mathrm{C}$ NMR spectra were consistent to literature data. ${ }^{8}$

\section{(1S,2R)-\{1-Benzyl-2-hydroxy-3-[isobutyl-(4-methoxy-benzenesulfonyl)-amino]-propyl\}-} carbamic acid benzofuran-5-yl ester (19a)

Following the general procedure the compound 19a was obtained as white solid (75\% yield). $[\alpha]^{20}{ }_{D}$ $=17.5\left(\mathrm{c} 0.5, \mathrm{CH}_{2} \mathrm{Cl}_{2}\right) .{ }^{1} \mathrm{H} \mathrm{NMR}\left(500 \mathrm{MHz}, \mathrm{CDCl}_{3}\right) \delta(\mathrm{ppm}): 7.65(\mathrm{~d}, J=8.7 \mathrm{~Hz}, 2 \mathrm{H}), 7.55(\mathrm{~d}, J=$ $2.4 \mathrm{~Hz}, 1 \mathrm{H}), 7.34(\mathrm{~d}, J=8.8 \mathrm{~Hz}, 1 \mathrm{H}), 7.25(\mathrm{~m}, 4 \mathrm{H}), 7.20(\mathrm{~m}, 1 \mathrm{H}), 7.11(\mathrm{bs}, 1 \mathrm{H}), 6.90(\mathrm{~d}, J=8.7$ $\mathrm{Hz}, 2 \mathrm{H}), 6.80$ (d, $J=8.8 \mathrm{~Hz}, 1 \mathrm{H}), 6.64(\mathrm{bs}, 1 \mathrm{H}), 5.14$ (d, $J=8.3 \mathrm{~Hz}, 1 \mathrm{H}), 3.87$ (bs, 2H), 3.78 (s, $3 \mathrm{H}), 3.74(\mathrm{bs}, 1 \mathrm{H}), 3.09\left(\mathrm{dd}, J_{1}=15.1 \mathrm{~Hz}, J_{2}=8.3 \mathrm{~Hz}, 1 \mathrm{H}\right), 3.01(\mathrm{~m}, 2 \mathrm{H}), 2.92(\mathrm{~m}, 2 \mathrm{H}), 2.75(\mathrm{dd}$, $\left.J_{1}=13.6 \mathrm{~Hz}, J_{2}=6.8 \mathrm{~Hz}, 1 \mathrm{H}\right), 1.79(\mathrm{~m}, 1 \mathrm{H}), 1.18(\mathrm{bs}, 1 \mathrm{H}), 0.87(\mathrm{~d}, J=6.5 \mathrm{~Hz}, 3 \mathrm{H}), 0.82(\mathrm{~d}, J=$ $6.5 \mathrm{~Hz}, 1 \mathrm{H}) .{ }^{13} \mathrm{C} \mathrm{NMR}\left(125 \mathrm{MHz}, \mathrm{CDCl}_{3}\right) \delta(\mathrm{ppm}): 163.1,155.2,152.4,146.4,146.2,137.5,129.7$, 129.6, 129.5, 128.7, 127.9, 126.7, 118.1, 114.4, 113.6, 111.6, 106.8, 72.5, 58.9, 55.6, 55.2, 53.8, 35.3, 27.3, 20.2, 19.9. MS (m/z): $567\left(\mathrm{MH}^{+}\right)$. Anal. Calcd for $\mathrm{C}_{30} \mathrm{H}_{34} \mathrm{~N}_{2} \mathrm{O}_{7} \mathrm{~S}: \mathrm{C}, 63.59 ; \mathrm{H}, 6.05 ; \mathrm{N}$, 4.94; O, 19.76; S, 5.66. Found C, 63.7; H, 6.1; N, 4.8; S, 5.6. 


\section{(1S,2R)-\{1-Benzyl-2-hydroxy-3-[isobutyl-(4-methoxy-benzenesulfonyl)-amino]-propyl\}-}

carbamic acid benzo[b]thiophen-5-yl ester (19b).

Following the general procedure the compound 19b was obtained as white solid (71\% yield). $[\alpha]^{20}{ }_{\mathrm{D}}=14.2\left(\mathrm{c} 0.5, \mathrm{CH}_{2} \mathrm{Cl}_{2}\right) .{ }^{1} \mathrm{H}$ NMR $\left(500 \mathrm{MHz}, \mathrm{CDCl}_{3}\right) \delta(\mathrm{ppm}): 7.78(\mathrm{~d}, J=8.5 \mathrm{~Hz}, 1 \mathrm{H}), 7.73$ $(\mathrm{d}, J=8.6 \mathrm{~Hz}, 2 \mathrm{H}), 7.48(\mathrm{~d}, J=5.6 \mathrm{~Hz}, 1 \mathrm{H}), 7.42(\mathrm{bs}, 1 \mathrm{H}), 7.32(\mathrm{~m}, 6 \mathrm{H}), 6.98(\mathrm{~d}, J=8.6 \mathrm{~Hz}, 2 \mathrm{H})$, $6.96(\mathrm{~d}, J=7.1 \mathrm{~Hz}, 1 \mathrm{H}), 5.40$ (bs, 1H), 3.98 (bs, 2H), 3.85 (s, 3H), 3.14 (m, 3H), 3.00 (m, 2H), 2.85 $\left(\mathrm{dd}, J_{1}=13.4 \mathrm{~Hz}, J_{2}=6.7 \mathrm{~Hz}, 1 \mathrm{H}\right), 1.88(\mathrm{~m}, 1 \mathrm{H}), 1.76(\mathrm{bs}, 1 \mathrm{H}), 0.95(\mathrm{~d}, J=6.5 \mathrm{~Hz}, 3 \mathrm{H}), 0.91(\mathrm{~d}, J$ $=6.5 \mathrm{~Hz}, 3 \mathrm{H}) .{ }^{13} \mathrm{C} \mathrm{NMR}\left(125 \mathrm{MHz}, \mathrm{CDCl}_{3}\right) \delta(\mathrm{ppm}): 163.1,154.9,148.0,140.1,137.5,136.6$, $129.7,129.5,129.4,128.6,128.0,126.6,123.6,122.8,118.6,115.8,114.3,72.5,58.7,55.6,55.3$, 53.7, 35.3, 27.2, 20.1, 19.9. MS (m/z): $583\left(\mathrm{MH}^{+}\right)$. Anal. Calcd for $\mathrm{C}_{30} \mathrm{H}_{34} \mathrm{~N}_{2} \mathrm{O}_{6} \mathrm{~S}_{2}: \mathrm{C}, 61.83 ; \mathrm{H}$, 5.88; N, 4.81; O, 16.47; S, 11.01. Found C, 61.9; H, 5.7; N, 4.8; S, 11.1.

\section{(1S,2R)-\{1-Benzyl-2-hydroxy-3-[isobutyl-(4-methoxy-benzenesulfonyl)-amino]-propyl\}-}

\section{carbamic acid 1H-indol-5-yl ester (19c).}

Following the general procedure the compound $19 \mathrm{c}$ was obtained as white solid $\left(70 \%\right.$ yield). $[\alpha]^{20}{ }_{D}$ $=-18.2(\mathrm{c} 1.0, \mathrm{MeOH}) .{ }^{1} \mathrm{H} \mathrm{NMR}\left(500 \mathrm{MHz}, \mathrm{CDCl}_{3}\right) \delta(\mathrm{ppm}): 8.13$ (bs, $\left.1 \mathrm{H}\right), 7.65(\mathrm{~d}, J=8.8 \mathrm{~Hz}$, 2H), $7.36(\mathrm{~m}, 4 \mathrm{H}), 7.20(\mathrm{~m}, 3 \mathrm{H}), 7.13(\mathrm{~m}, 2 \mathrm{H}), 6.89(\mathrm{~d}, J=8.8 \mathrm{~Hz}, 2 \mathrm{H}), 6.72(\mathrm{~d}, J=8.5 \mathrm{~Hz}, 1 \mathrm{H})$, 6.42 (bs, 1H), 5.09 (bd, $J=7.8 \mathrm{~Hz}, 1 \mathrm{H}), 3.85$ (bs, 2H), 3.78 (s, 3H), 3.04 (m, 3H), 2.90 (m, 2H), $2.76\left(\mathrm{dd}, J_{1}=13.4 \mathrm{~Hz}, J_{2}=6.5 \mathrm{~Hz}, 1 \mathrm{H}\right), 1.80(\mathrm{~m}, 1 \mathrm{H}), 0.86(\mathrm{~d}, J=6.5 \mathrm{~Hz}, 3 \mathrm{H}), 0.83(\mathrm{~d}, J=6.5 \mathrm{~Hz}$, $3 \mathrm{H}) .{ }^{13} \mathrm{C} \mathrm{NMR}\left(125 \mathrm{MHz}, \mathrm{CDCl}_{3}\right) \delta(\mathrm{ppm})$ 163.0, 155.8, 144.4, 137.5, 133.5, 129.8, 129.6, 129.5, 128.6, 128.1, 126.6, 125.5, 116.2, 114.4, 112.7, 111.2, 102.9, 72.6, 55.6, 55.3, 53.8, 35.3, 27.3, 20.0, 19.8.MS $(\mathrm{m} / z)$ : $566\left(\mathrm{MH}^{+}\right)$. Anal. Calcd for $\mathrm{C}_{30} \mathrm{H}_{35} \mathrm{~N}_{2} \mathrm{O}_{7} \mathrm{~S}: \mathrm{C}, 63.70 ; \mathrm{H}, 6.24 ; \mathrm{N}, 7.43 ; \mathrm{O}$, 16.97; S, 5.67. Found C, 63.8; H, 6.1; N, 7.4; S, 5.6.

\section{Modeling}

The docking runs were carried out on the reference pdb structure 3NU3, complex of wild type HIV protease with amprenavir. The ligand and water molecules were removed from the structure, while hydrogens and charges were added with MGLTools. The inhibitors molecules were prepared and optimized with the MMFF forcefield as implemented in Spartan 10 (Wave Function Inc.). The size of the docking grid was $65 \times 50 \times 40 \AA$, comprising the whole protein. MD refinement of the complexes was carried out at $300{ }^{\circ} \mathrm{K}$ in the NTV ensemble with 500 ps runs. 


\section{Biology}

Dulbecco's Modified Eagle Medium (DMEM), dimethyl sulfoxide (DMSO), 3-(4,5dimethylthiazol-2-yl)-2,5-diphenyltetrazolium bromide (MTT) and Darunavir were purchased from Sigma Aldrich (Milan, Italy). Trypsin-EDTA solution, Fetal Bovine Serum (FBS), glutamine, penicillin-streptomycin and Phosphate Buffered Saline (PBS) were purchased from Euroclone (Milan, Italy). QuikChange XL Site-Directed Mutagenesis Kit was purchased from Agilent Technologies.

\section{Cell culture and drug treatment}

Human embryonic kidney (HEK293) cells were maintained in DMEM supplemented with 10\% FBS, $2 \mathrm{mM}$ L-glutamine, $100 \mathrm{U} / \mathrm{ml}$ penicillin and $100 \mu \mathrm{g} / \mathrm{ml}$ streptomycin at $37^{\circ} \mathrm{C}$ in a humidified incubator with 5\% $\mathrm{CO}_{2}$. HIV-protease inhibitors were dissolved in DMSO to a stock concentration of $30 \mathrm{mM}$ and diluted with complete DMEM to get the required concentrations. The final DMSO concentration in the cell cultures was no greater than $0.8 \%$ : this concentration does not affect cell viability. DMSO treated cells were used as control in all the experiments.

\section{Cell viability analysis}

Cell viability was determined considering that cells with active metabolism are able to convert MTT, a water-soluble tetrazolium salt, into a purple colored formazan product with an absorbance maximum near $570 \mathrm{~nm}^{15}$. Died cells lose the ability to convert MTT into formazan, thus color formation serves as a useful marker of only the viable cells. Briefly, HEK293 cells were plated in 96-well plates at a density of $1 \times 10^{4}$ cells/well and treated for $24 \mathrm{~h}$ with various concentrations of each HIV-1 protease inhibitor $(12.5,25,50$ and $100 \mu \mathrm{M})$. Cells were then incubated with MTT solution $\left(0.5 \mathrm{mg} / \mathrm{ml}\right.$ in DMEM) for $4 \mathrm{~h}$ at $37^{\circ} \mathrm{C}$. The formazan crystals were finally dissolved in DMSO : isopropanol (1:1) solution. The absorbance was measured at a wavelength of $570 \mathrm{~nm}$, with background subtraction at 630-690 nm, using a GLOMAX Multidetection System.

\section{Generation of HIV-1 protease variants}

HIV-1 protease mutants (V32I and V82A) were generated with QuikChange XL Site-Directed Mutagenesis Kit, according to the manufacturer's instructions, using pcDNA3-GFP-PR as a template $^{16}$. Mutagenic primers were designed using Quick Change Primer Design Program available online at www.agilent.com/genomics/qcpd/ and each mutation was verified by sequencing. 


\section{Cell Transfection, Fluorescence microscopy and flow cytometric analysis}

Transfection experiments in HEK293 cells were performed, as previously described ${ }^{5}$, by cationic lipid transfection reagent (Trans-IT 2020, Mirus) using $0.5 \mu \mathrm{g}$ of the expression vectors pcDNA3GFP-PR (gift from Nico Dantuma, Addgene plasmid \# 20253) and V32I and V82A variants. Cells were collected 24 hours after transfection. Where indicated, immediately after transfection, cells were treated with $10 \mu \mathrm{M}$ or $30 \mu \mathrm{M}$ of each HIV-1 protease inhibitor. Darunavir (DRV) $10 \mu \mathrm{M}$ was used as positive control. For fluorescence microscopy, cells were grown on coverslips, fixed with 4\% paraformaldehyde in PBS and observed under a fluorescent microscope (Nikon 80i). Analysis of GFP fluorescence was carried out resuspending cells in PBS and detecting signal using a FACS Canto II flow cytometer (Ex/Em: 480/510 nm).

\section{Acknowledgments}

Financial support has been provided by MIUR (Italian Ministry of University) PON Ricerca e Innovazione 2014-2020 - Area SALUTE - ARS01 01081, "Prodotti INnovativi ad alto contenuto biotecnologico per il settore BIOMEDicale” (INBIOMED) and University of Basilicata.

\section{References and Notes}

\footnotetext{
${ }^{1}$ Global Report: UNAIDS report on the global AIDS epidemic 2017. WHO Library Cataloguing-in-Publication Data, Joint United Nations Programme on HIV/AIDS (UNAIDS), 2017.

2 (a) Wensing A. M. J., Van Maarseveen N. M., Nijhuis M. Antiviral Res. 2010; 85, 59-74; (b) Mitsuya H., Maeda K., Das D., Ghosh A. K. In Advances in Pharmacology. Jeang K.-T. ed. Amsterdam: Elsevier, 2007, 56, 169-197; (c) Ghosh A. K., Chapsal B. D. Aspartic acid proteases as therapeutic targets. In: Ghosh AK, editor. Methods and Principles in Medicinal Chemistry, 2010, Vol. 45 Weinheim: Wiley-VCH,169-204.

3 (a) Ghosh A. K., Rao K. V., Nyalapatla, P. R., Kovela S., Brindisi M., Osswald H. L., Reddy B. S., Agniswamy J., Wang Y-F, Aoki M., Hattori S-I., Weber I. T., Mitsuya H. Chem Med Chem 2018, 13, 803-815; (b) Ghosh A. K., Williams J. N., Ho R. Y., Simpson H. M., Hatton S.-I., Hayashi H., Agniswamy J., Wang Y- F., Weber I. T. J. Med. Chem. 2018, 61, 9722-9737.

${ }^{4}$ (a) Bonini C., Chiummiento L., Di Blasio N., Funicello M., Lupattelli P., Tramutola F., Berti F., Ostric A., Miertus S., Frecer V., Kong D.-X. Bioorg Med Chem. 2014, 22, 4792-4802; (b) Cerminara I., Chiummiento L., Funicello M., Guarnaccio A., Lupattelli P. Pharmaceuticals 2012, 5, 297-316; (c) Chiummiento L., Funicello M., Lupattelli P., Tramutola F., Berti F., Marino-Merlo F. Bioorg. Med. Chem. Lett. 2012, 22, 2948-2950; (d) Bonini C., Chiummiento L., De Bonis M., Di Blasio N., Funicello M., Lupattelli P., Pandolfo R., Tramutola F., Berti F. J Med Chem. 2010, 53, 1451-1457; (e) Chiummiento L., Funicello M., Lupattelli P., Tramutola F., Campaner P. Tetrahedron 2009, 65, 59845989.

${ }^{5}$ Funicello M., Chiummiento L., Tramutola F., Armentano M. F., Bisaccia F., Miglionico R., Milella L., Benedetti F., Berti F., Lupattelli P. Bioorganic \& Medicinal Chemistry 2017, 25, 4715-4722.

${ }^{6}$ (a) Bian J., Li X., Wang N., Wu X., You Q., Zhang, X. Eur. J. Med. Chem. 2017, 129, 27-40; (b) Cerminara I., D’Alessio L., D’Auria M., Funicello M., Guarnaccio A. Helvetica Chimica Acta 2016, 99, 384-392; (c) Yamaguchi, Y., Akimoto, I., Motegi, K., Yoshimura, T., Wada, K., Nishizono, N., Oda, K. Chem. Pharm. Bull. 2013, 61, 997-1001; (d) Bonini C., Cristiani G., Funicello M., Viggiani L. Synthetic Communications 2006, 1983-1990; (e) Pérez-Silanes S., Martínez-Esparza J., Oficialdegui A. M., Villanueva H., Orús L., Monge A. J. Heter. Chem. 2001, 38, $1025-1030$. ${ }^{7}$ Liu J.-T., Do T. J., Simmons C. J., Lynch J. C., Gu W., Ma Z.-X., Xu W. Tang, W. Org. Biomol. Chem 2016, 14, 8927-8930.

8 (a) Bai X., Yang Z., Zhu M., Dong B., Zhu L., Zhang G., Wang J., Wang Y. Eur. J. Med. Chem. 2017, 137, 30-44; (b) Yang Z.-H., Bai X.-G., Zhou, L., Wang J.-X., Liu H.-T., Wang Y.-C. Bioorg. Med. Chem. Lett. 2015, 25, $1880-1883$.
} 
9 (a) Maksimovic-Ivanic, D., Fagone P., McCubrey J., Bendtzen K., Mijatovic S., Nicoletti F. Int. J. Cancer, 2017, 140, 1713-1726; (b) Facchinetti V., Moreth M., Gomes, C. R. B., Do Ó Pessoa C., Rodrigues F. A. R., Cavalcanti B. C., Oliveira A. C. A., Carneiro T. R., Lelis Gama I., De Souza M. V. N. Med. Chem. Res. 2015, 24, 533-542.

10 Trott O., Olson A.J. J. Comput. Chem. 2010, 31, 455-461.

${ }^{11}$ Hess B., Kutzner C., Van der Spoel D., Lindahl E. J Chem Theory Comput. 2008, 4, 435-447

12 Callebaut et al. Antimicrob. Agents Chemother. 2011, 55, 1366

${ }^{13}$ Lindsten K., Uhlikova T., Konvalinka J., Masucci M.G., Dantuma N.P. Antimicrob Agents Chemother. 2001, 45, $2616-2622$.

${ }^{14}$ Majerova-Uhlikova T., Dantuma N. P., Lindsten K., Masucci M.G., Konvalinka J., Journ. of Clinical Virology, 2006, 36, 50-59.

15 Armentano M.F., Bisaccia F., Miglionico R., Russo D., Nolfi N., Carmosino M., Andrade P.B., Valentão P., Diop M.S., Milella L. Biomed Res Int. 2015, 561-589.

${ }^{16}$ Miglionico R., Gerbino A., Ostuni A., Armentano M.F., Monné M., Carmosino M., Bisaccia F. J Bioenerg Biomembr. 2016, 48, 259-267 